\title{
Combinations of siRNAs against La Autoantigen with NS5B or hVAP-A Have Additive Effect on Inhibition of HCV Replication
}

\author{
Anirban Mandal, ${ }^{1}$ Krishna Kumar Ganta, ${ }^{1}$ and Binay Chaubey ${ }^{1,2}$ \\ ${ }^{1}$ Centre for Advance Studies, Department of Botany, University of Calcutta, 35 Ballygunge Circular Road, Kolkata 700019, India \\ ${ }^{2}$ Laboratory of Recombinant Vaccines, Intercollegiate Faculty of Biotechnology, UG and MUG, Abrahama 58 Street, \\ 80-307 Gdańsk, Poland
}

Correspondence should be addressed to Binay Chaubey; bchaubey@hotmail.com

Received 28 March 2016; Revised 23 May 2016; Accepted 30 May 2016

Academic Editor: Piero Luigi Almasio

Copyright (C) 2016 Anirban Mandal et al. This is an open access article distributed under the Creative Commons Attribution License, which permits unrestricted use, distribution, and reproduction in any medium, provided the original work is properly cited.

\begin{abstract}
Hepatitis $\mathrm{C}$ virus is major cause of chronic liver diseases such as chronic hepatitis, liver cirrhosis, and hepatocellular carcinoma. Presently available direct-acting antiviral drugs have improved success rate; however, high cost limits their utilization, especially in developing countries like India. In the present study, we evaluated anti-HCV potential of several siRNAs targeted against the HCV RNA-dependent RNA polymerase NS5B and cellular factors, La autoantigen, PSMA7, and human VAMP-associated protein to intercept different steps of viral life cycle. The target genes were downregulated individually as well as in combinations and their impact on viral replication was evaluated. Individual downregulation of La autoantigen, PSMA7, hVAP-A, and NS5B resulted in inhibition of HCV replication by about $67.2 \%, 50.7 \%, 39 \%$, and $52 \%$, respectively. However, antiviral effect was more pronounced when multiple genes were downregulated simultaneously. Combinations of siRNAs against La autoantigen with NS5B or hVAP-A resulted in greater inhibition in HCV replication. Our findings indicate that siRNA is a potential therapeutic tool for inhibiting $\mathrm{HCV}$ replication and simultaneously targeting multiple viral steps with the combination of siRNAs is more effective than silencing a single target.
\end{abstract}

\section{Introduction}

$\mathrm{HCV}$ is an enveloped, single-stranded positive sense, RNA virus belonging to Flaviviridae family that causes acute and chronic hepatitis in humans. Persistent HCV infection often leads to cirrhosis and hepatocellular carcinoma [1]. Currently, 130-150 million people are chronically infected with HCV and $\sim 0.5$ million people die every year due to HCV related liver diseases [2]. World Health Organization (WHO) has recognized hepatitis $\mathrm{C}$ as a global health problem [3]. Till 2011, the mainstay of the HCV therapy has been a combination of pegylated interferon alfa (PEG-IFN $\alpha$ ) in combination with ribavirin $[4,5]$. The addition of telaprevir and boceprevir (NS3/4A protease inhibitors) to this arsenal improved success rate, but rapid development of drug resistance, severe side effects, and low spectrum activity proved to be barriers to treatment, and therefore it is no longer used after interferonfree regimens became widely available [6-9]. HCV treatment has been further improved with the recent introduction of HCV NS5B inhibitor sofosbuvir and NS5A inhibitor ledipasvir [10]. In early 2016 second-generation NS3/4A protease inhibitor grazoprevir and second-generation NS5A inhibitor elbasvir were approved for the treatment of genotypes 1 and 4 infected patients [11]. However, due to the poor replicative fidelity of HCV, frequent emergences of drug-resistant strains are inevitable. Furthermore, high cost and genotype dependency of these drugs often lead to treatment noncompliance $[12,13]$. This necessitates a continuing effort to design and develop additional agents to combat HCV.

RNA interference (RNAi) is a gene silencing phenomenon during which small dsRNA molecules induce sequencespecific degradation of homologous endogenous mRNA [14, 15]. In general, $\mathrm{HCV}$ is highly susceptible to RNAi because $\mathrm{HCV}$ genome is a (+) single-stranded RNA which functions as both messenger RNA and template for replication in the cytoplasm of hepatocyte [16]. Silencing of HCV RNA could 
stop its replication and propagation. Therefore, utilization of this technology holds tremendous potential as a therapeutic tool against HCV. Previous reports have shown that silencing of cellular or viral determinants could inhibit HCV entry and replication [17-23]. siRNAs targeted against the core and NS4B regions specifically decreased viral load in a dosedependent manner [24]. siRNAs against NS5B and NS3 regions inhibit $\mathrm{HCV}$ replication and protein expression without any IFN response [25]. Alternatively, many studies have also been focused on the cellular factors that directly or indirectly interact with the different regions of the viral genome and play a vital role in viral life cycle [26-29]. However, monotherapy with siRNA has led to the emergence of viral escape mutants through point mutation within the siRNA target regions [30, 31]. Therefore, combinations of siRNAs comprising multiple viral and/or cellular targets have also been evaluated. Few recent reports showed that combinations of siRNAs targeted against different cellular or viral factors have synergistic anti-HCV effects [32-36]. Most of these studies were restricted to either viral entry or the viral genome. However, different stages in HCV life cycle, such as viral entry, viral genome translation, replication complex formation and replication, and virion assembly and release, represent a broader spectrum of molecular events that may serve as potential targets against HCV. Therefore, we propose cocktail of siRNAs targeting different viral and cellular factors which may intercept various crucial steps in the viral life cycle and may enforce a strong synergistic antiviral effect.

In the present study, gene specific siRNAs were designed against cellular factors, La autoantigen, PSMA7, hVAP-A, and viral factor $\mathrm{HCV}$ NS5B and screened for $\mathrm{HCV}$ inhibition individually as well as in combinations. These cellular factors and viral protein NS5B play crucial roles in HCV life cycle [37-45]. Downregulation of viral replications was assessed by semiquantitative RT-PCR, western blotting, and immunostaining.

\section{Materials and Methods}

2.1. Cell Culture. Huh-7.5 cells (a kind gift from Dr. V. N. Pandey, New Jersey Medical School, USA), a highly permissive cell line for HCV replication, were grown in Dulbecco's Modified Eagle's Medium (Gibco, USA) supplemented with $10 \%$ FBS (Gibco, USA), penicillin $100 \mathrm{U} / \mathrm{mL}$ and streptomycin $100 \mu \mathrm{g} / \mathrm{mL}$ (HiMedia, India), $0.1 \mathrm{mM}$ nonessential amino acids (Gibco, USA), and $2 \mathrm{mM}$ glutamax-I (Gibco, USA). Cells were maintained in a humidified incubator at $37^{\circ} \mathrm{C}$ in $5 \% \mathrm{CO}_{2}$.

2.2. HCV Production in Cell Culture. For HCV culture, pFLJ6/JFH plasmid [24] (a kind gift from Dr. V. N. Pandey, New Jersey Medical School, USA) encoding full-length chimeric $\mathrm{HCV}$ genotype 2a was linearized with $\mathrm{XbaI}$ and subjected to in vitro transcription using MEGAscript Kit (Ambion, USA) following manufacturer's protocol. Huh-7.5 cells were transfected with $10 \mu \mathrm{g}$ transcript using Lipofectamine 2000 transfection reagent (Invitrogen, USA) using manufacturer's protocol and $6 \mathrm{~h}$ after transfection media were removed, cells were washed with PBS and incubated in fresh media.
The culture supernatant was collected after $72 \mathrm{~h}$ and passed through $0.45 \mu \mathrm{m}$ filter and stored at $-80^{\circ} \mathrm{C}$ in small aliquots.

2.3. Viral Load Quantification. Viral RNAs were isolated from cell culture supernatants using Trizol LS reagent (Ambion, USA) and quantified by real-time quantitative RTPCR using primer pair of HCV $5^{\prime} \mathrm{UTR}$ : forward, $5^{\prime}$-CCTAATAGGGGCGACACTCCG- $3^{\prime}$; reverse, $5^{\prime}$-CCACAAGGCCTTTCGCAACC-3'. Assays were performed using Sybr green real-time PCR master mix reagent kit (Invitrogen, USA) and mastercycler ep realplex2 (Eppendorf, Germany) according to the manufacturer's instructions.

2.4. RNA Isolation and RT-PCR. Total RNA was extracted from cells using Trizol reagent (Ambion, USA) following manufacturer's guidelines. RNA was then subjected to cDNA synthesis using RevertAid reverse transcriptase (Thermo Fisher Scientific, USA) following manufacturer's protocol in a thermocycler (Eppendorf, Germany). In brief, cDNA was synthesized using $2 \mu \mathrm{g}$ of total RNA in $20 \mu \mathrm{L}$ reaction volume using gene specific reverse primers and further $2 \mu \mathrm{L}$ of cDNA was used for PCR amplification of specific genes. Respective primer sequences were La autoantigen: forward, 5'-GGATAGACTTCGTCAGAGGAGCA-3'; reverse, 5' CTGGTCTCCAGCACCATTTTCTG- $3^{\prime}$; hVAP-A: forward, $5^{\prime}$-GTGCTCCATCTGATTTACCCCA-3'; reverse, $5^{\prime}$-TTCCACAGGCTTGCTCAGTATT-3'; PSMA7: forward, $5^{\prime}$ GCCATCACCGTCTTCTCGCC-3 ${ }^{\prime}$; reverse, $5^{\prime}$-CGTTGTCATCCAAAGCACAG-3'; HCV NS5B: forward, $5^{\prime}$-ACATCAAGTCCGTGTGGAAGG-3'; reverse, $5^{\prime}$-GCTCCCATTACCGCCTGAGG-3'; and $\beta$-actin: forward, $5^{\prime}$-GCGGGAAATCGTGCGTGACATT- $3^{\prime}$; reverse, $5^{\prime}$-GATGGAGTTGAAGGTAGTTTCGTG-3'. The PCR products were resolved by electrophoresis in $1.5 \%(\mathrm{w} / \mathrm{v})$ agarose gels and images were captured by a Chemidoc XRS system (Bio-Rad, USA). The band intensities were quantified using Quantity One software.

2.5. Design and Synthesis of siRNAs. siRNAs were designed using IDT online designing tool and were synthesized from IDT, USA. Sequences of siRNAs were as follows: La autoantigen (GenBank accession number NM_003142): sense, $5^{\prime}$ GGAACAAAGAAGUGACUU-3'; antisense, $5^{\prime}$-ACUUCCCAAGUCACUUCU-3 ${ }^{\prime}$; hVAP-A (GenBank accession number NM_194434.2): sense, 5'-GGUUUAGACAGGUUCAAUUAGCUCA-3'; antisense, 5'-UGAGCAAAUUGAACCUGUCUAAACCCG- $3^{\prime}$; PSMA7 (GenBank accession number NM_002792.3): sense, $5^{\prime}$-CCUCUUCCAAGUGGAGUA-3'; antisense, $5^{\prime}$-CUGCGCGUACUCCACUUG-3'; HCV NS5B (HCV genotype 2a strain): sense, $5^{\prime}$-CCCUCUAUGACAUUACACA-3'; antisense, $5^{\prime}$-UGUGUAAUGUCAUAGAGGG-3'; scrambled negative control: sense, $5^{\prime}$ CUUCCUCUCUUUCUCUCCCUUGUGA-3'; antisense, 5'-UCACAAGGGAGAGAAAGAGAGGAAGGA-3'.

2.6. siRNA Transfection and HCV Infection. Huh-7.5 cells $\left(2 \times 10^{5}\right.$ cells/well) grown overnight in 12 -well plates were transiently transfected with $50 \mathrm{nM}$ for single and $100 \mathrm{nM}$ for combinations of siRNAs using Lipofectamine RNAiMAX 
transfection reagent (Invitrogen, USA) as per manufacturer's protocol. After $48 \mathrm{~h}$ of transfection, cells were infected with an equal amount of HCV (MOI 1:0.1) and incubated for $4 \mathrm{~h}$. Cells were once again transfected with siRNAs to maintain the gene silencing effect and incubated for another $48 \mathrm{~h}$. Total RNA or protein was isolated and subjected to RTPCR or western blotting, respectively. Scrambled siRNA, noncomplementary to any known sequence in the human and HCV genome, was included as a negative control.

2.7. Western Blotting. For western blotting, cells were lysed with RIPA buffer (50 mM Tris-Cl, $5 \mathrm{mM}$ EDTA, $150 \mathrm{mM}$ $\mathrm{NaCl}, 1 \%$ Triton X-100, $1 \%$ sodium deoxycholate, and $1 \%$ sodium dodecyl sulfate) supplemented with $1 \mathrm{mM}$ protease inhibitor, PMSF, and then centrifuged at $13,000 \mathrm{rpm}$ for $10 \mathrm{~min}$ at $4^{\circ} \mathrm{C}$. Supernatants were collected and total protein was quantified by Bradford method. Equal amount of protein $(20 \mu \mathrm{g})$ from the control and transfected cells was subjected to SDS-PAGE and then transferred to a PVDF membrane (GE healthcare, USA). After blocking with 5\% BSA, blots were incubated overnight at $4^{\circ} \mathrm{C}$ with primary antibodies specific for La autoantigen (ab75927, Abcam, UK), HCV NS5B (sc-34040, Santa Cruz Biotechnology, USA), and $\beta$-actin (NB100-56874, Novus Biologicals, USA). Membranes were incubated with corresponding secondary antibodies conjugated with horseradish peroxidase (sc-2005, sc-2354, and sc2004, Santa Cruz Biotechnology, USA). The blots were developed using ECL chemiluminescence detection kit (Bio-Rad, USA) by a Chemidoc XRS system (Bio-Rad, USA) and band intensities were quantified using Quantity One software [46].

2.8. Indirect Immunofluorescence. Huh- 7.5 cells $\left(5 \times 10^{4}\right.$ cells/ well) grown on $17 \mathrm{~mm}$ poly-D-lysine coated glass coverslips (MP Biomedicals, USA) were fixed with $4 \%$ paraformaldehyde for $20 \mathrm{~min}$ at room temperature. Cells were washed twice with PBS and then permeabilized with $0.2 \%$ TritonX100 for 10 min followed by blocking with 3\% BSA in PBS. After blocking, cells were incubated overnight at $4^{\circ} \mathrm{C}$ with primary antibody specific for HCV NS5B (sc-34040, Santa Cruz Biotechnology, USA). Cells were then incubated with FITC conjugated secondary antibody (sc-2356, Santa Cruz Biotechnology, USA) for one hour at room temperature and then mounted the coverslips on glass slides with mounting media $(50 \mathrm{mM}$ Tris $\mathrm{pH} 8,150 \mathrm{mM} \mathrm{NaCl}$, and $1 \mathrm{mg} / \mathrm{mL}$ pphenylenediamine in 50\% glycerol) containing $400 \mathrm{nM}$ DAPI and observed under a confocal laser scanning microscope (Olympus Fluoview FV1000) [47].

2.9. Cellular Viability Assay. The cytotoxicity of siRNA-Lipofectamine RNAiMAX complex was assessed by MTT [3-(4,5dimethylthiazol-2-yl)-2,5-diphenyltetrazolium bromide] assay [48]. Huh-7.5 cells grown overnight in 96-well plate $(20,000$ cells/well $)$ were transfected with individual or combination of siRNAs and incubated for $72 \mathrm{~h}$. After incubation, $20 \mu \mathrm{L}$ of $5 \mathrm{mg} / \mathrm{mL}$ MTT reagent (HiMedia Laboratories, India) was added to each well and incubated for $4 \mathrm{~h}$ at $37^{\circ} \mathrm{C}$. The formazan crystals were dissolved in acidified isopropanol solution and absorbance was taken in a microplate reader
(iMark Microplate Reader, Bio-Rad, USA) at $595 \mathrm{~nm}$ with a reference wavelength of $650 \mathrm{~nm}$.

2.10. Statistical Analysis. Data are presented as mean \pm standard deviation $(n=3)$ and one-way ANOVA test was performed using SPSS software (version 22.0.0.0). $P$ value $<0.05$ versus control was considered statistically significant.

\section{Result}

3.1. Downregulation of Cellular and Viral Genes Severely Inhibits HCV Replication. HCV NS5B, an RNA-dependent RNA polymerase, synthesizes viral genome through an intermediate negative RNA strand. Hence, it is an important target to inhibit the viral replication. Among the host cell factors, La autoantigen, an RNA-binding protein, plays an important role in viral translation and replication and protects viral RNA from rapid degradation [37-39]. Expression of La autoantigen is induced by HCV infection, and it activates telomerase activity in Huh-7.5 cells. Therefore, it could be important to suppress La autoantigen protein not only for the inhibition of HCV, but also for reducing the oncogenic potential of hepatocytes infected with HCV [49]. PSMA7, $\alpha$ subunits of $20 \mathrm{~S}$ proteasome, regulates HCV-IRES (internal ribosome entry site) mediated cap-independent viral translation, a phenomenon essential for HCV replication. Furthermore, inhibition of the $20 \mathrm{~S}$ proteasome by proteasome inhibitor exerts a dose-dependent inhibition on HCV-IRES activity [40]. Another host cell factor, hVAP-A, a SNARE-like vesicle transport protein, is present in the ER and ER/Golgi intermediate compartment (ERGIC) and plays a general role in vesicle traffic between the ER and Golgi compartment [50]. It makes a bridge between viral proteins NS5B and NS5A by making its N-terminus interact with NS5B and C-terminus interact with NS5A and mediates the formation of $\mathrm{HCV}$ replication complex on a lipid raft [41]. We downregulated these viral and host genes using single and combinatorial RNAi-based approach in Huh-7.5 cells infected with HCV and evaluated its effect on viral replication.

We found that siRNA targeted against La autoantigen mRNA reduced its expression by $96.5 \%$ in HCV-infected Huh-7.5 cells and consequently HCV replication was also reduced by $67.2 \%$ (Figures $1(\mathrm{a})$ and $1(\mathrm{~b})$ ) indicating a direct impact of downregulation of La autoantigen on viral replication. Similarly, there was $39 \%$ reduction in viral replication upon $50.1 \%$ downregulation of hVAP-A (Figures 1(c) and $1(\mathrm{~d})$ ) and $65 \%$ downregulation of PSMA7 resulted in 50.7\% lower level of HCV level (Figures 1(e) and 1(f)). These observations clearly indicate a reduction in $\mathrm{HCV}$ replication in response to downregulation of selected cellular genes, involved in viral life cycle. Similarly, HCV propagation was also inhibited by $52 \%$ compared to control upon treatment with siRNA targeted against NS5B region of HCV genome (Figures $1(\mathrm{~g})$ and $1(\mathrm{~h})$ ).

3.2. Effects of Combinatorial Gene Silencing on HCV Replication. In order to determine the effect of simultaneous downregulation of multiple genes on HCV replication, Huh-7.5 


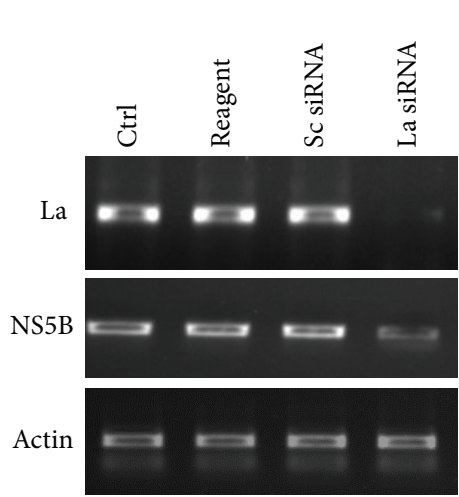

(a)

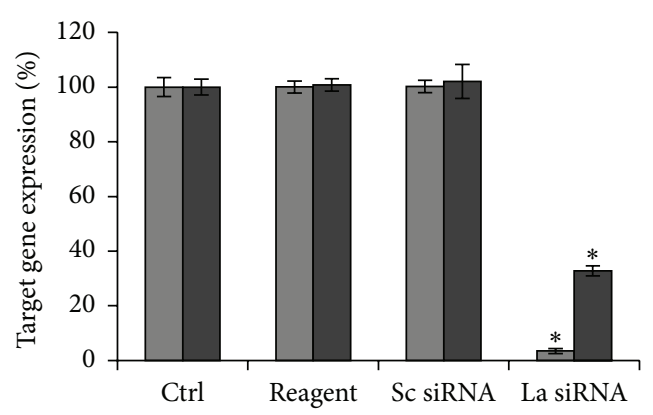

$\square \quad$ La autoantigen

$\square$ NS5B

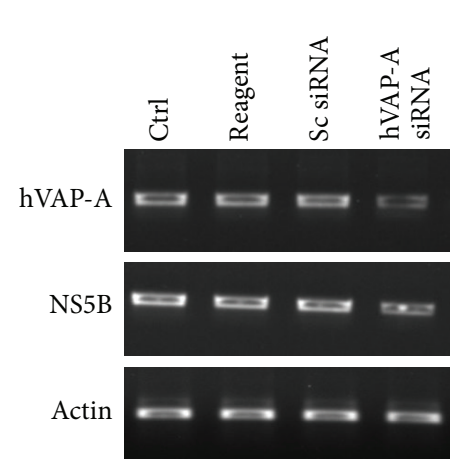

(c)

(b)

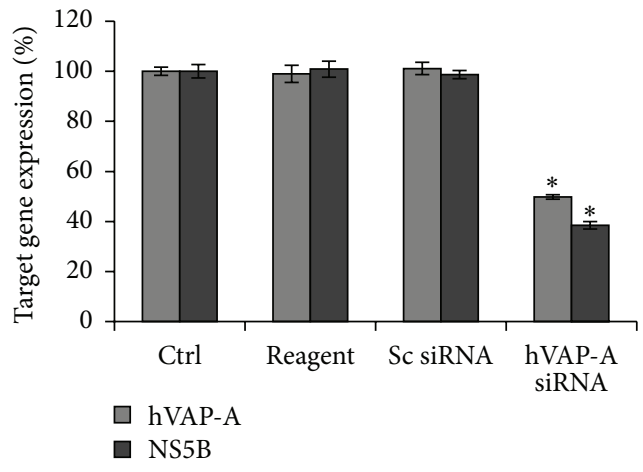

(d)
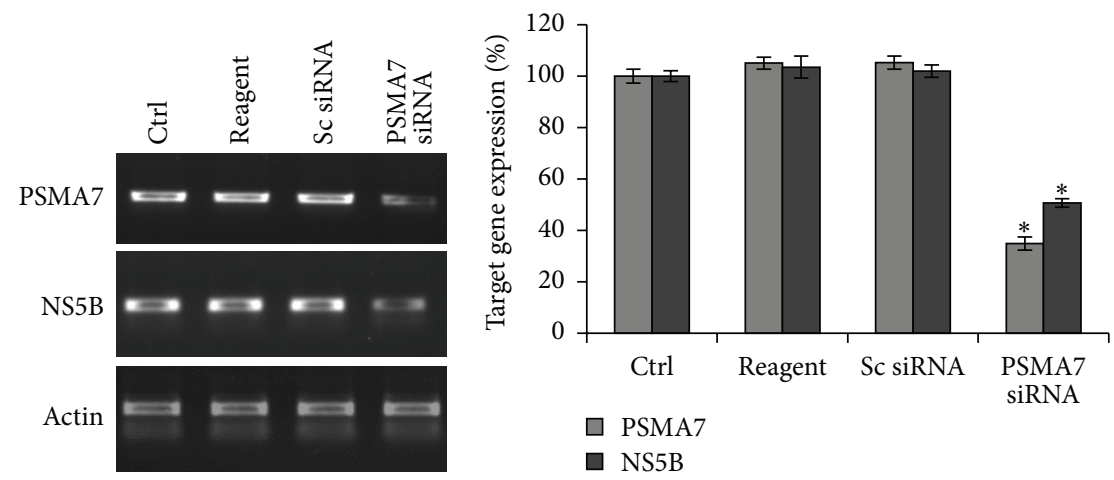

(f)

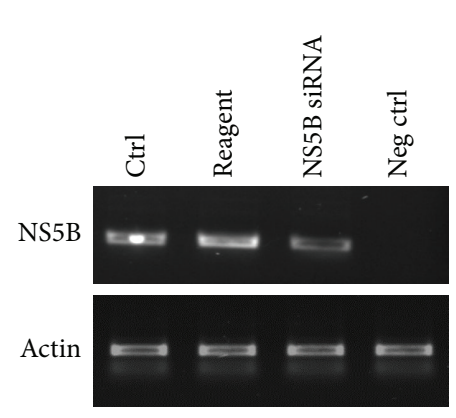

(g)

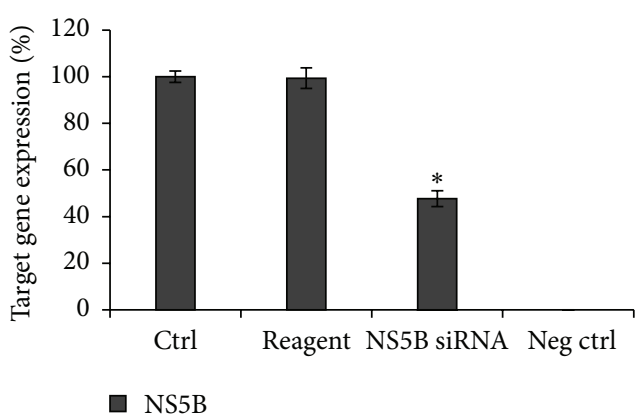

(h)

FigURE 1: Downregulation of La autoantigen, hVAP-A, PSMA7, and NS5B leads to reduction in viral replication: overnight grown Huh-7.5 cells were transfected with La autoantigen, hVAP-A, and PSMA7 siRNAs for $48 \mathrm{~h}$. Cells were then infected with the virus and again transfected with same siRNAs. After incubation total RNA was isolated and subjected to RT-PCR. NS5B siRNA was transfected once only after cells were infected. (a), (c), (e), and (g) represent RT-PCR results for target genes and NS5B gene upon treatment with La autoantigen, hVAP-A, PSMA7, and NS5B siRNAs, respectively. Densitometric analysis of (a), (c), (e), and (g) images is expressed in percentage in (b), (d), (f), and (h), respectively. The data represent mean \pm standard deviation. ${ }^{*} P$ value $<0.05$ versus control considered statistically significant. 


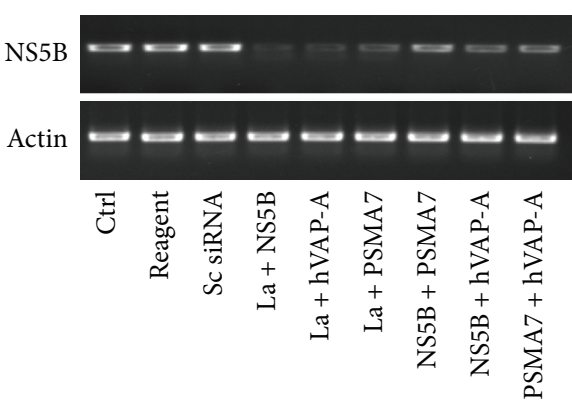

(a)

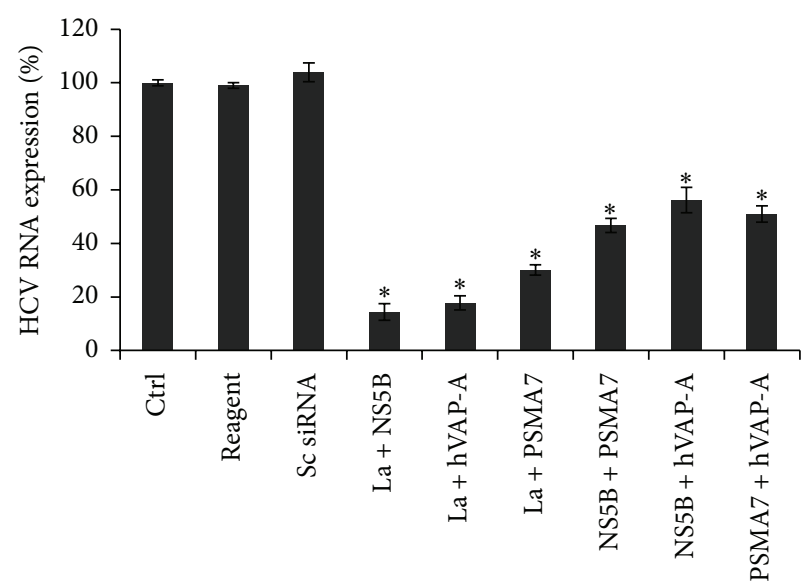

- NS5B

(b)

FIGURE 2: Simultaneous downregulation of multiple genes more effectively inhibits HCV replication: Huh-7.5 cells in a similar experimental setup as mentioned in Figure 1 were transfected with following combinations of siRNAs: La autoantigen + NS5B, La autoantigen + hVAP-A, La autoantigen + PSMA7, NS5B + hVAP-A, NS5B + PSMA7, and PSMA7 + hVAP-A. Downregulation of viral replication were determined by RT-PCR as shown in (a). (b) represents densitometry analysis of HCV NS5B downregulation. The data represent mean \pm standard deviation. ${ }^{*} P$ value $<0.05$ versus control was considered statistically significant.

TABLE 1: Effect of siRNAs used individually and in combination on HCV replication. Only combination of La autoantigen with hVAP-A or HCV NS5B shows syndergistic effect on HCV inhibition. Other combinations of siRNAs could not improve the overall level of inhibition of HCV.

\begin{tabular}{|c|c|c|c|c|c|c|}
\hline \multirow{2}{*}{$\begin{array}{l}\text { Target gene (siRNA } \\
\text { position) }\end{array}$} & \multirow{2}{*}{$\begin{array}{l}\text { Target gene } \\
\text { silencing (\%) }\end{array}$} & \multirow{2}{*}{$\begin{array}{l}\text { Reduction of HCV after } \\
\text { single gene silencing (\%) }\end{array}$} & \multicolumn{4}{|c|}{ Reduction of HCV after multiple gene silencing (\%) } \\
\hline & & & (+) La autoantigen & (+) hVAP-A & (+) PSMA7 & $(+)$ NS5B \\
\hline $\begin{array}{l}\text { La autoantigen } \\
(1064-1081)\end{array}$ & 96.5 & 67.2 & - & - & - & - \\
\hline hVAP-A (5929-5953) & 50.1 & 39.0 & $82.2 \uparrow$ & - & - & - \\
\hline $\begin{array}{l}\text { PSMA7 } \\
(199-217)\end{array}$ & 65.0 & 50.7 & $69.9 \uparrow$ & $49.0 \downarrow$ & - & - \\
\hline $\begin{array}{l}\text { HCV NS5B } \\
(531-549)\end{array}$ & 52.0 & 52.0 & $85.6 \uparrow$ & $53.3 \downarrow$ & $43.8 \downarrow$ & - \\
\hline
\end{tabular}

cells were transfected with the following combinations of siRNAs: La autoantigen + NS5B, La autoantigen + hVAP-A, La autoantigen + PSMA7, NS5B + PSMA7, NS5B + hVAP-A, and PSMA7 + hVAP-A. Viral replication was reduced by $85.6 \%, 82.2 \%, 69.9 \%, 43.8 \%, 53.3 \%$, and $49.0 \%$ with combinations of La autoantigen + NS5B, La autoantigen + hVAP-A, La autoantigen + PSMA7, NS5B + PSMA7, NS5B + hVAP-A, and PSMA7 + hVAP-A siRNAs, respectively (Figure 2). The combination of La autoantigen + hVAP-A siRNAs reduced the HCV replication by $82.2 \%$ while it was $67.2 \%$ and $39 \%$, respectively, when the genes were downregulated individually (Figure 1). Similarly, the combination of La autoantigen + NS5B siRNAs also inhibited the HCV replication by $85.6 \%$, whereas the individual downregulation of La autoantigen and NS5B genes demonstrated $67.2 \%$ and $52 \%$ inhibition of viral replication, respectively (Figure 1). These results indicate synergistic anti-HCV effects due to simultaneous downregulation of La autoantigen + hVAP-A or La autoantigen + NS5B on viral replication. However, similar synergistic effects on viral replication were not observed after simultaneous downregulation of La autoantigen + PSMA7, NS5B + PSMA7, NS5B + hVAP-A, or PSMA7 + hVAP-A siRNAs. This indicates that multiplexing any combination of siRNAs is not sufficient to have a synergistic antiviral effect (Table 1). Their roles in viral biology are crucial to be effective antiviral targets.

3.3. Combinatorial Effect of La Autoantigen with NS5B siRNA on HCV Protein Expression. We further checked the inhibitory effect of downregulation of La autoantigen and HCV NS5B on the expression of the viral protein by western blot analysis. We found that combination of La autoantigen + NS5B siRNA demonstrated 95\% reduction in NS5B protein levels compared with $73 \%$ and $54.5 \%$, respectively, when the genes were downregulated individually (Figures 3(a) and 3(b)). Similar results were obtained from immunostaining of NS5B protein. As shown in Figure 3(c), downregulation of the viral protein NS5B was observed and it was found that cells treated with combination of siRNAs showed a cumulative effect on HCV inhibition compared to individual siRNAs treated cells. Cytotoxicity for all the siRNAs was measured at 


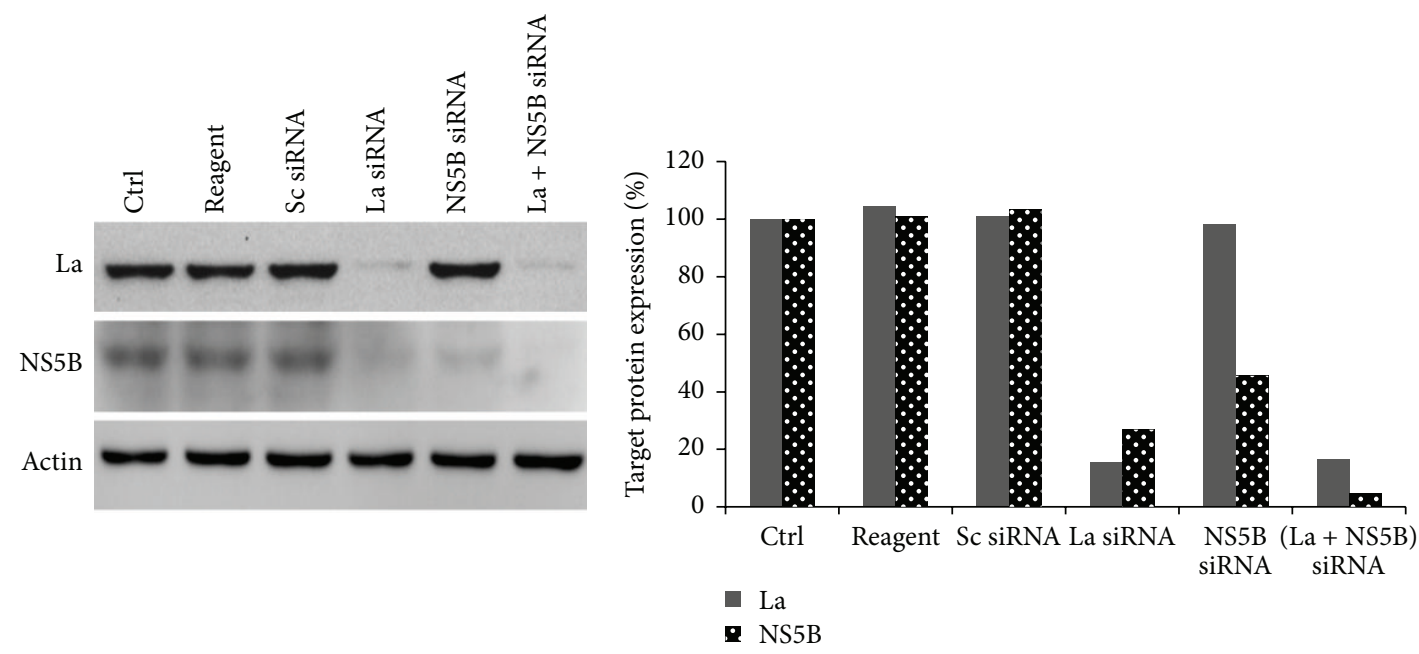

(a)

(b)
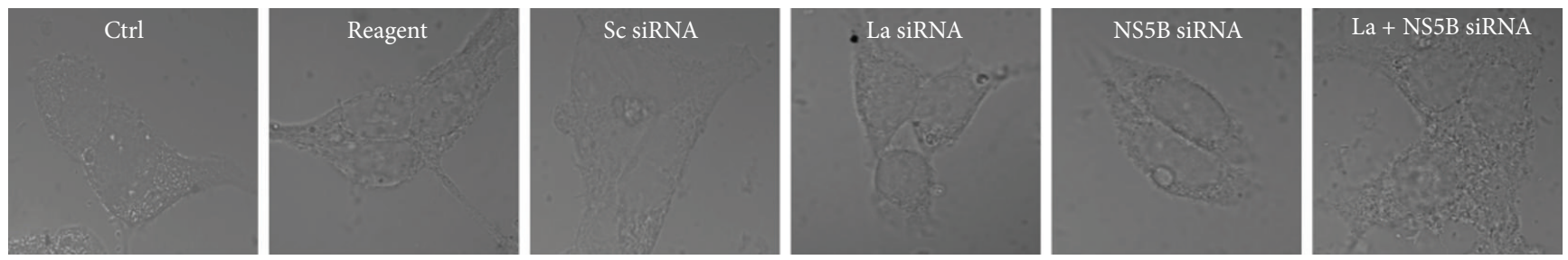

(A)
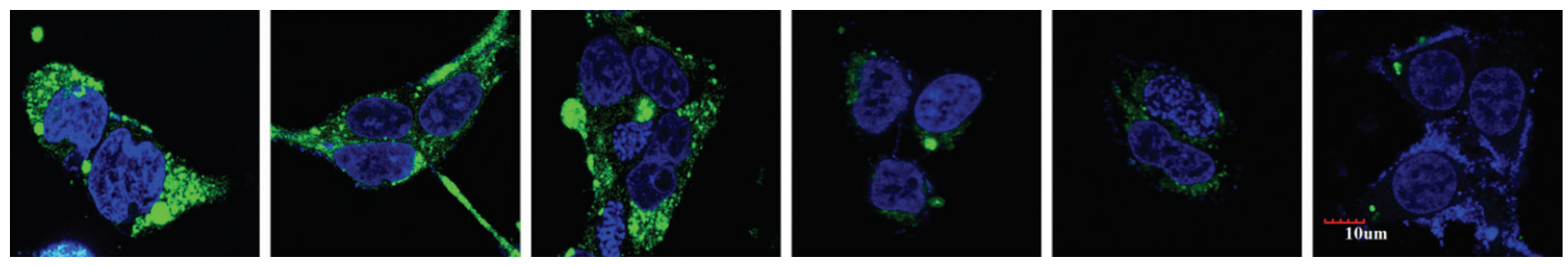

(B)

(c)

FIGURE 3: Analysis of NS5B protein expression after transfecting NS5B and La autoantigen siRNAs: HCV-infected Huh-7.5 cells were treated with siRNAs against La autoantigen and NS5B as mentioned above. After $48 \mathrm{~h}$ total cellular protein was isolated and subjected to western blot analysis. (a) indicates downregulation of La autoantigen (upper gel) and NS5B (middle gel) and $\beta$-actin (lower gel). (b) represents densitometric analysis of La autoantigen and HCV NS5B expressed in percentage. Immunofluorescence of NS5B from single and combination of siRNAs transfected cells as represented in (c) where row (A) indicates cells in bright field and row (B) is the merging of DAPI and FITC stained cells.

$50 \mathrm{nM}$ (for single siRNAs) and $100 \mathrm{nM}$ (for combinations of siRNAs) and no significant effect was observed on cell growth and viability upon treatment with test or control siRNAs (Figure 4).

\section{Discussion}

The HCV life cycle is broadly divided into following major steps: entry and uncoating, translation, replication, assembly, and release of virion particles, as depicted in Figure $5[51,52]$. Each of these steps involves interactions with the host cell factors which are crucial to establish infection and maintain the viral life cycle $[53,54]$. Interventions of these interactions can severely impair the viral life cycle. Cellular factors hVAPA, La autoantigen, and PSMA7 have multiple roles during distinct stages of HCV life cycle and are potential targets for host targeting antivirals (HTA) as depicted in the schematic model of HCV life cycle in Figure 5 [37-43, 55, 56].

During uncoating, the internalized viral nucleocapsid fuses with endosomal membranes and release its genome into the cytosol [57]. Alteration in cholesterol composition in the endosomal compartment can inhibit this step. hVAP-A with oxysterol-binding protein (OSBP) is involved in cholesterol homeostasis which in turn helps endocytic release of virion into the cytosol $[42,43]$. Therefore, downregulation of hVAPA inhibits the fusion of clathrin coated virion with endosomal membranes, thereby inhibiting then invasion step. In 


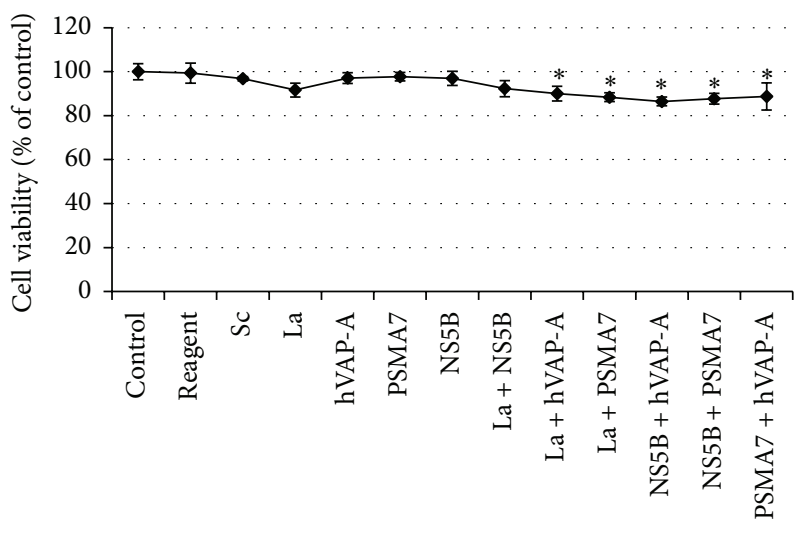

FIGURE 4: Cytotoxicity assay of single and different combinations of siRNAs: Huh-7.5 cells grown for $24 \mathrm{~h}$ in a 96-well plate were transiently transfected with single or different combination of siRNAs and incubated for $72 \mathrm{~h}$. Cell viability was then determined by MTT assay. Absorbance was taken at $595 \mathrm{~nm}$ by a microplate reader and readings were plotted as percentage. The data represent mean \pm standard deviation. ${ }^{*} P$ value $<0.05$ versus control was considered statistically significant.

the present study upon $50.1 \%$ downregulation of hVAP-A, HCV was also inhibited by $39 \%$ (Figures 1(c) and 1(d)). However, upon more efficient downregulation of hVAP-A $\sim 60 \%$ reduction in HCV replication has also been observed [58]. Short hairpin against hVAP-A expressed through an adenoviral vector effectively inhibits the HCV replication [59]. Variations in the level of downregulation of target gene and HCV could be attributed to the silencing efficiency of siRNA as well as different HCV strains.

Following entry into the cytosol, the viral RNA becomes highly susceptible to siRNA-mediated degradation. A number of groups have shown that NS5B is an important factor for HCV replication and an attractive antiviral drug target $[60,61]$. We designed siRNA targeting the active site of HCV NS5B, a highly conserved region among different HCV genotypes. As expected, upon downregulation of NS5B gene significant decrease in viral RNA and protein expression was observed (Figures 1(g), 1(h), and 3). Several groups have directed siRNAs against different regions of viral genome including NS5B and demonstrated different levels of inhibition of viral replication and protein expression $[62,63]$. During HCV life cycle several cellular factors bind to the viral RNA at different regions in order to help with translation and replication or to protect viral RNA [26, 37-39, 64]. The cellular factor La autoantigen binds to the U-rich region of HCV $3^{\prime}$ UTR and shield viral RNA from degradation [39]. Therefore, lower expression of La autoantigen makes the viral RNA vulnerable to cellular nucleases.

$\mathrm{HCV}$ uses host translation machinery and several cellular factors to synthesize polyprotein precursor. La autoantigen also binds to the initiator AUG codon of $5^{\prime} U T R$ and facilitates efficient HCV-IRES mediated translation [38]. In our study when La autoantigen was downregulated by $96.5 \%$, consequently reduction of $67.2 \%$ in HCV level was also observed (Figures 1(a) and 1(b)). In few studies, La autoantigen was used as a therapeutic target for successful inhibition of $\mathrm{HCV}$, although the extent of inhibition of target gene and HCV varied among different studies due to different siRNA target regions, experimental setup, or efficiency of siRNA delivery $[58,59]$. PSMA7 has been implicated for its role in IRES mediated translation of HCV [40]. We downregulated PSMA7 by $65 \%$ and as a result of this viral replication was also reduced by $50.7 \%$ (Figures $1(\mathrm{e})$ and $1(\mathrm{f})$ ). About $50 \%$ inhibition of $\mathrm{HCV}$ replication has also been observed when PSMA7 expression was downregulated by the siRNA delivered through retroviral vector [36].

HCV makes a replication complex within cholesterol-rich lipid raft membrane using viral nonstructural proteins, NS3, NS4A, NS4B, NS5A, and NS5B, and cellular protein hVAPA. The cellular factor makes a bridge between viral proteins NS5B and NS5A [41]. Therefore, due to downregulation of hVAP-A the association of HCV nonstructural proteins on lipid raft membrane is severely disturbed which consequently hampers viral replication. Several cellular factors and HCV nonstructural proteins are involved during viral replication $[65,66]$. La autoantigen and PSMA7 have been involved at this stage and hence downregulation of these genes severely affected the viral replication (Figures 1(a), 1(b), 1(e), and 1(f)). Therefore, these cellular proteins are the important anti-HCV target. The overall schematic model of HCV life cycle and siRNA-mediated inhibition at different steps has been shown in Figure 5.

It is also important to confirm that silencing of these cellular genes has no lethal effects on the host. La autoantigen influences RNA polymerase III transcription in vitro [67], but depletion does not hamper the transcription rate synthesized by class III RNA polymerase although reduction in ribonucleoprotein (RNP) formation has been observed [68]. hVAPA is predominantly involved in vesicle trafficking between membrane compartments including endoplasmic reticulum and Golgi complex $[69,70]$ and reduction of hVAP-A may affect the vesicle transport functions of cells. siRNA-mediated inhibition of PSMA7 reduced vesicular stomatitis viral replication through enhanced production of virus-induced type I IFN [71]; still it may be speculated that downregulation may hamper the intracellular proteolysis. However, MTT assay on cells transfected with all the siRNAs individually or in combination showed no significant changes in cellular viability compared with the nontransfected controls (Figure 4).

When multiple genes were downregulated and more than one viral step was challenged, inhibition of HCV was more pronounced (Table 1). Viral replication was reduced by $85.6 \%$ and $82.2 \%$ particularly with combinations of siRNAs against La autoantigen with NS5B or hVAP-A, respectively, as compared to other combinations of siRNAs (Figure 2). These observations confirmed that downregulation of La autoantigen along with NS5B or hVAP-A facilitates inhibition of HCV replication cooperatively. These results were also confirmed by western blotting and immunostaining (Figure 3(c)). The combination of La autoantigen with NS5B simultaneously targets the viral RNA, translation, and replication steps. Similarly, when La autoantigen and hVAP-A were simultaneously downregulated viral uncoating, translation, replication complex formation, replication, and viral RNA were concurrently 


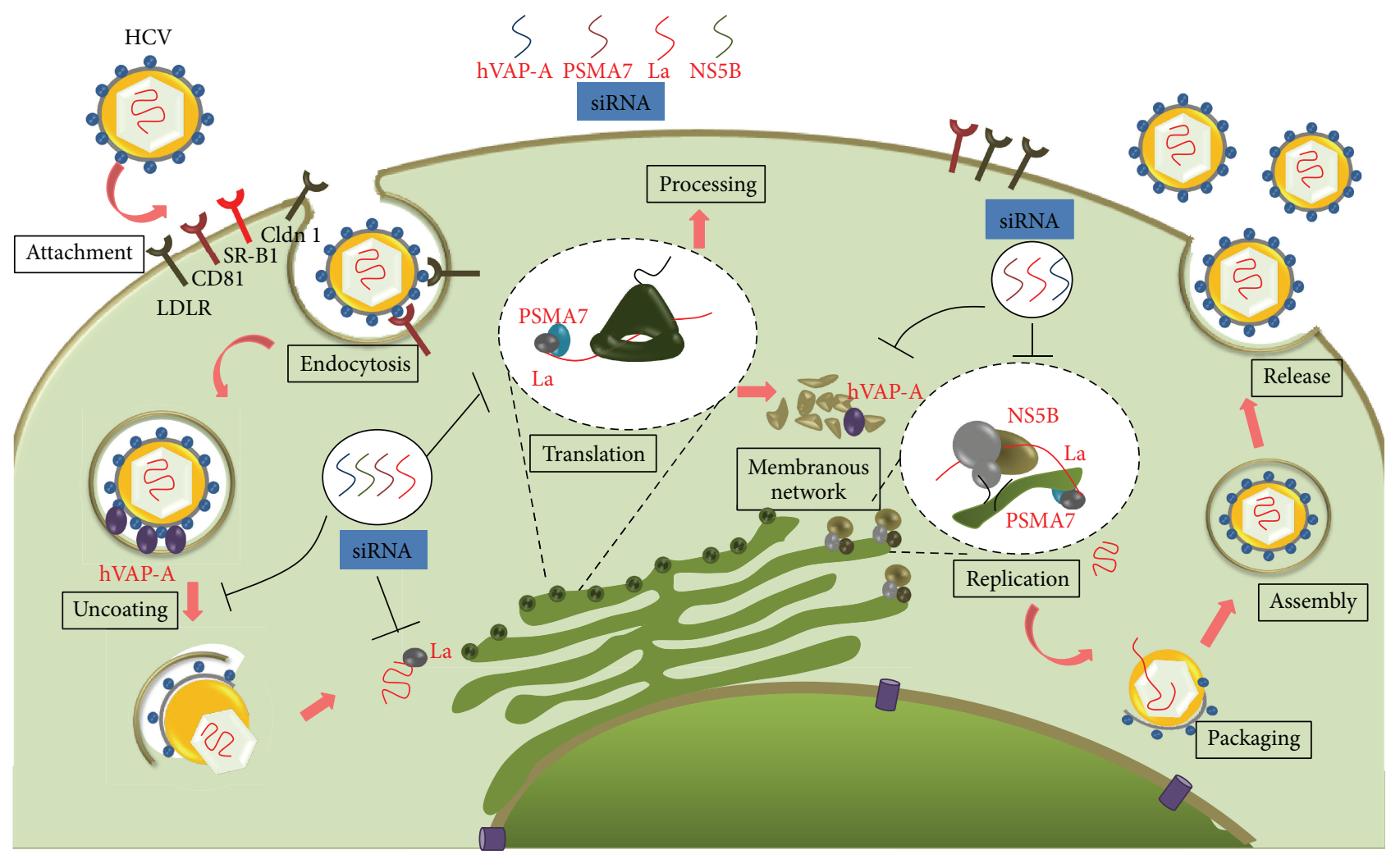

Figure 5: Schematic model of HCV life cycle and siRNA-mediated inhibition of different steps: After receptor-mediated entry, host protein hVAP-A interacts in the uncoating and replication complex formation step within the membranous web network region. Therefore, downregulating hVAP-A with siRNA severely affects the viral replication. siRNA against La autoantigen and PSMA7 simultaneously hinder viral translation and replication step. La autoantigen also binds to the $3^{\prime}$ UTR of viral RNA and protects it from cellular nuclease; hence downregulation of La autoantigen makes the viral RNA susceptible to nuclease. NS5B siRNA was directed against the NS5B conserved region of viral RNA.

affected. A few recent studies exhibited the effect of combinatorial RNAi on HCV replication. Enhanced reduction in $\mathrm{HCV}$ entry was noted after downregulation of entry receptors CD81 along with LDLR or SR-BI [33]. In another study, dual siRNAs directed against HCV $5^{\prime}$ UTR rapidly inhibit viral replication and also minimized escape mutants [34]. Adenoassociated viral (AAV) vector expressed multiple short hairpin oligos against HCV NS5B and HCV $5^{\prime}$ UTR has shown long lasting $\mathrm{HCV}$ inhibition in a nonhuman primate model [35]. siRNAs against HCV envelope protein E2 along with entry receptor LDLR or CD81 showed an enhanced reduction in HCV entry [32]. However, these studies were targeted to either viral entry or the viral genome. Virus is often able to escape the single inhibitory blocks created by antivirals and capable of perpetuating its life cycle. Therefore, targeting multiple steps at the same time is more realistic approach in order to inhibit HCV more effectively and prevent escape mutants. It is pertinent to mention that designing of siRNA and selection of viral and cellar targets are the key to the success of siRNA based inhibition of HCV. Application of siRNA has tremendous possibilities because it not just allows downregulating host and viral factors simultaneously but also allows tremendous flexibility in designing of siRNAs with dynamic changes in the viral sequences.

\section{Conclusion}

Currently approved anti-HCV drugs are mainly genotype dependent and because of error prone replication of $\mathrm{HCV}$ emergence of quasi-species are inevitable. Targeting conserved regions among different genotypes can reduce emergence of resistant strains and also inhibit virus in a pangenotypic manner. Targeting host cell factor is a novel approach particularly for patients who fail to respond to current direct antiviral agents (DAA) treatment or develop drug resistance. As siRNAs work at mRNA level the host DNA remains unaffected and emergence of mutational resistance to the host or the virus does not arise, therefore, creating a possibility of pan-genotypic anti-HCV treatment. Several studies showed that siRNAs targeted against different regions (stem-loops II, III, and IV) of $5^{\prime}$ UTR or cellular factor CD81 inhibit HCV infection in genotype-independent manner [72-74]. Therefore, siRNA has tremendous potential as a therapeutic tool against HCV. We showed simultaneous inhibition of La autoantigen with NS5B or hVAP-A is more effective than silencing a single gene to inhibit the viral replication. Therefore, a cocktail of siRNAs directed against different crucial steps in viral life cycle is likely to be a more effective approach in the treatment of chronic hepatitis C. 


\section{Ethical Approval}

The authors state that present study did not involve any human or animal experimental investigations.

\section{Competing Interests}

The authors declare that there is no conflict of interests regarding the publication of this paper.

\section{Acknowledgments}

The authors would like to thank the Department of Biotechnology, New Delhi, India, for financial support vide Sanction no. BT/PR9284/Med/29/61/2007.

\section{References}

[1] T. Kanda, O. Yokosuka, and M. Omata, "Hepatitis C virus and hepatocellular carcinoma," Biology, vol. 2, no. 1, pp. 304-316, 2013.

[2] World Health Organization, "Hepatitis C," Fact Sheet Number 164, World Health Organization, Geneva, Switzerland, 2015, http://www.who.int/mediacentre/factsheets/fs164/en/.

[3] World Health Organization, Hepatitis C, World Health Organization, Geneva, Switzerland, 2003, http://www.who.int/csr/disease/hepatitis/Hepc.pdf.

[4] J. J. Feld and J. H. Hoofnagle, "Mechanism of action of interferon and ribavirin in treatment of hepatitis C," Nature, vol. 436, no. 7053, pp. 967-972, 2005.

[5] R. T. Chung, M. Gale Jr., S. J. Polyak, S. M. Lemon, T. J. Liang, and J. H. Hoofnagle, "Mechanisms of action of interferon and ribavirin in chronic hepatitis C: summary of a workshop," Hepatology, vol. 47, no. 1, pp. 306-320, 2008.

[6] K. J. Wilby, N. Partovi, J.-A. E. Ford, E. D. Greanya, and E. M. Yoshida, "Review of boceprevir and telaprevir for the treatment of chronic hepatitis C," Canadian Journal of Gastroenterology, vol. 26, no. 4, pp. 205-210, 2012.

[7] A. A. Butt and F. Kanwal, "Boceprevir and telaprevir in the management of hepatitis C virus-infected patients," Clinical Infectious Diseases, vol. 54, no. 1, pp. 96-104, 2012.

[8] HIVandHepatitis.com, "Vertex to Discontinue Sale of Telaprevir (Incivek) for Hepatitis C," San Francisco, Cailf, USA, 2014, http://www.hivandhepatitis.com/hcv-treatment/approved-hcvdrugs/4808-vertex-to-discontinue-sale-of-telaprevir-incivekfor-hepatitis-c.

[9] HIVandHepatitis.com, Merck Plans to Discontinue Boceprevir for Hepatitis C by December 2015, HIVandHepatitis.com, San Francisco, Calif, USA, 2015, http://www.hivandhepatitis.com/ hcv-treatment/approved-hcv-drugs/5021-merck-plans-to-discontinue-boceprevir-for-hepatitis-c-by-december- 2015.

[10] N. Afdhal, K. R. Reddy, D. R. Nelson et al., "Ledipasvir and sofosbuvir for previously treated HCV genotype 1 infection," The New England Journal of Medicine, vol. 370, no. 16, pp. 14831493, 2014.

[11] M. P. Manns, J. M. Vierling, B. R. Bacon et al., "The combination of MK-5172, peginterferon, and ribavirin is effective in treatment-naive patients with hepatitis c virus genotype 1 infection without cirrhosis," Gastroenterology, vol. 147, no. 2, pp. 366-376.e6, 2014.
[12] G. Diana and H. Gregory, "Ledipasvir/sofosbuvir (Harvoni): improving options for hepatitis C virus infection," $P$ \& $T$, vol. 40, no. 4, pp. 256-276, 2015.

[13] FDA News Release, "FDA approves Zepatier for treatment of chronic hepatitis C genotypes 1 and 4," U.S. Food and Drug Administration, Silver Spring, Md, USA, 2016, http://www .fda.gov/NewsEvents/Newsroom/PressAnnouncements/ucm483828.htm.

[14] A. Reynolds, D. Leake, Q. Boese, S. Scaringe, W. S. Marshall, and A. Khvorova, "Rational siRNA design for RNA interference," Nature Biotechnology, vol. 22, no. 3, pp. 326-330, 2004.

[15] G. J. Hannon, "RNA interference," Nature, vol. 418, no. 6894, pp. 244-251, 2002.

[16] M. Motavaf, S. Safari, and S. M. Alavian, “Therapeutic potential of RNA interference: a new molecular approach to antiviral treatment for hepatitis C," Journal of Viral Hepatitis, vol. 19, no. 11, pp. 757-765, 2012.

[17] J. A. Wilson, S. Jayasena, A. Khvorova et al., "RNA interference blocks gene expression and RNA synthesis from hepatitis C replicons propagated in human liver cells," Proceedings of the National Academy of Sciences of the United States of America, vol. 100, no. 5, pp. 2783-2788, 2003.

[18] J.-S. Moon, S.-H. Lee, E.-J. Kim et al., "Inhibition of hepatitis $\mathrm{C}$ virus in mice by a small interfering RNA targeting a highly conserved sequence in viral IRES pseudoknot," PLOS ONE, vol. 11, no. 1, Article ID e0146710, 2016.

[19] T. Kanda, R. Steele, R. Ray, and R. B. Ray, "Small interfering RNA targeted to hepatitis $C$ virus 5 ' nontranslated region exerts potent antiviral effect," Journal of Virology, vol. 81, no. 2, pp. 669-676, 2007.

[20] S. Khaliq, S. Jahan, B. Ijaz, W. Ahmad, S. Asad, and S. Hassan, "Inhibition of hepatitis $\mathrm{C}$ virus genotype 3 a by siRNAs targeting envelope genes," Archives of Virology, vol. 156, no. 3, pp. 433442, 2011.

[21] H. Ding, Y. Liu, Z.-Q. Bian et al., "Stably silencing of CD81 expression by small interfering RNAs targeting 3/-NTR inhibits HCV infection," Hepatitis Monthly, vol. 8, no. 4, pp. 267-274, 2008.

[22] G. Randall, M. Panis, J. D. Cooper et al., "Cellular cofactors affecting hepatitis C virus infection and replication," Proceedings of the National Academy of Sciences of the United States of America, vol. 104, no. 31, pp. 12884-12889, 2007.

[23] S. Jahan, B. Samreen, S. Khaliq et al., "HCV entry receptors as potential targets for siRNA-based inhibition of HCV," Genetic Vaccines and Therapy, vol. 9, article 15, 2011.

[24] G. Randall, A. Grakoui, and C. M. Rice, "Clearance of replicating hepatitis $\mathrm{C}$ virus replicon RNAs in cell culture by small interfering RNAs," Proceedings of the National Academy of Sciences of the United States of America, vol. 100, no. 1, pp. 235240, 2003.

[25] Y. Takigawa, M. Nagano-Fujii, L. Deng et al., "Suppression of hepatitis $\mathrm{C}$ virus replicon by RNA interference directed against the NS3 and NS5B regions of the viral genome," Microbiology and Immunology, vol. 48, no. 8, pp. 591-598, 2004.

[26] D. Harris, Z. Zhang, B. Chaubey, and V. N. Pandey, "Identification of cellular factors associated with the 3/-nontranslated region of the hepatitis C virus genome," Molecular and Cellular Proteomics, vol. 5, no. 6, pp. 1006-1018, 2006.

[27] D. M. Jones, P. Domingues, P. Targett-Adams, and J. McLauchlan, "Comparison of U2OS and Huh-7 cells for identifying host factors that affect hepatitis C virus RNA replication," Journal of General Virology, vol. 91, no. 9, pp. 2238-2248, 2010. 
[28] T. I. Ng, H. Mo, T. Pilot-Matias et al., "Identification of host genes involved in hepatitis $\mathrm{C}$ virus replication by small interfering RNA technology," Hepatology, vol. 45, no. 6, pp. 1413-1421, 2007.

[29] A. W. Tai, Y. Benita, L. F. Peng et al., "A functional genomic screen identifies cellular cofactors of hepatitis $C$ virus replication," Cell Host \& Microbe, vol. 5, no. 3, pp. 298-307, 2009.

[30] M. Konishi, C. H. Wu, M. Kaito et al., "siRNA-resistance in treated HCV replicon cells is correlated with the development of specific HCV mutations," Journal of Viral Hepatitis, vol. 13, no. 11, pp. 756-761, 2006.

[31] J. A. Wilson and C. D. Richardson, "Hepatitis C virus replicons escape RNA interference induced by a short interfering RNA directed against the NS5b coding region," Journal of Virology, vol. 79, no. 11, pp. 7050-7058, 2005.

[32] S. Jahan, S. Khaliq, B. Samreen et al., "Effect of combined siRNA of HCV E2 gene and HCV receptors against HCV," Virology Journal, vol. 8, article 295, 2011.

[33] S. Jahan, B. Samreen, S. Khaliq et al., "HCV entry receptors as potential targets for siRNA-based inhibition of HCV," Genetic Vaccines and Therapy, vol. 9, no. 1, article 15, 2011.

[34] P. K. Chandra, A. K. Kundu, S. Hazari et al., "Inhibition of hepatitis $\mathrm{C}$ virus replication by intracellular delivery of multiple siRNAs by nanosomes," Molecular Therapy, vol. 20, no. 9, pp. 1724-1736, 2012.

[35] D. A. Suhy, S.-C. Kao, T. Mao et al., "Safe, long-term hepatic expression of anti-HCV shRNA in a nonhuman primate model," Molecular Therapy, vol. 20, no. 9, pp. 1737-1749, 2012.

[36] M. Korf, D. Jarczak, C. Beger, M. P. Manns, and M. Krüger, "Inhibition of hepatitis $\mathrm{C}$ virus translation and subgenomic replication by siRNAs directed against highly conserved HCV sequence and cellular HCV cofactors," Journal of Hepatology, vol. 43, no. 2, pp. 225-234, 2005.

[37] A. M. Domitrovich, K. W. Diebel, N. Ali, S. Sarker, and A. Siddiqui, "Role of La autoantigen and polypyrimidine tractbinding protein in HCV replication," Virology, vol. 335, no. 1, pp. 72-86, 2005.

[38] N. Ali and A. Siddiqui, “The La antigen binds 5 ' noncoding region of the hepatitis $c$ virus RNA in the context of the initiator AUG codon and stimulates internal ribosome entry site-mediated translation," Proceedings of the National Academy of Sciences of the United States of America, vol. 94, no. 6, pp. 2249-2254, 1997.

[39] K. Spångberg, L. Wiklund, and S. Schwartz, "Binding of the La autoantigen to the hepatitis $\mathrm{C}$ virus $3 /$ untranslated region protects the RNA from rapid degradation in vitro," Journal of General Virology, vol. 82, no. 1, pp. 113-120, 2001.

[40] M. Krüger, C. Beger, P. J. Welch, J. R. Barber, M. P. Manns, and F. Wong-Staal, "Involvement of proteasome $\alpha$-subunit PSMA7 in hepatitis $\mathrm{C}$ virus internal ribosome entry site-mediated translation," Molecular and Cellular Biology, vol. 21, no. 24, pp. 8357-8364, 2001.

[41] L. Gao, H. Aizaki, J.-W. He, and M. M. C. Lai, "Interactions between viral nonstructural proteins and host protein hVAP33 mediate the formation of hepatitis $\mathrm{C}$ virus RNA replication complex on lipid raft," Journal of Virology, vol. 78, no. 7, pp. 3480-3488, 2004.

[42] P. Metz, A. Reuter, S. Bender, and R. Bartenschlager, "Interferon-stimulated genes and their role in controlling hepatitis $\mathrm{C}$ virus," Journal of Hepatology, vol. 59, no. 6, pp. 1331-1341, 2013.

[43] S. Amini-Bavil-Olyaee, Y. J. Choi, J. H. Lee et al., "The antiviral effector IFITM3 disrupts intracellular cholesterol homeostasis to block viral entry," Cell Host and Microbe, vol. 13, no. 4, pp. 452-464, 2013.

[44] W. Zhong, A. S. Uss, E. Ferrari, J. Y. N. Lau, and Z. Hong, "De novo initiation of RNA synthesis by hepatitis $\mathrm{C}$ virus nonstructural protein 5B polymerase," Journal of Virology, vol. 74, no. 4, pp. 2017-2022, 2000.

[45] V. Lohmann, A. Roos, F. Körner, J. O. Koch, and R. Bartenschlager, "Biochemical and structural analysis of the NS5B RNA-dependent RNA polymerase of the hepatitis C virus," Journal of Viral Hepatitis, vol. 7, no. 3, pp. 167-174, 2000.

[46] S. Gallagher, S. E. Winston, S. A. Fuller, and J. G. R. Hurrell, "Immunoblotting and immunodetection," in Current Protocols in Molecular Biology, F. M. Ausubel, Ed., chapter 10, unit 10.8, pp. 10.8.1-10.8.28, John Wiley \& Sons, New York, NY, USA, 2008.

[47] J. G. Donaldson, "Immunofluorescence staining," in Current Protocols in Cell Biology, K. S. Morgan, Ed., chapter 4, unit 4.3, pp. 4.3.1-4.3.6, John Wiley \& Sons, New York, NY, USA, 1998.

[48] T. Mosmann, "Rapid colorimetric assay for cellular growth and survival: application to proliferation and cytotoxicity assays," Journal of Immunological Methods, vol. 65, no. 1-2, pp. 55-63, 1983.

[49] T. Shirasaki, M. Honda, H. Mizuno et al., "La protein required for internal ribosome entry site-directed translation is a potential therapiutic target for hepaatitis $\mathrm{C}$ virus replication," The Journal of Infectious Diseases, vol. 202, no. 1, pp. 75-85, 2010.

[50] M. L. Weir, A. Klip, and W. S. Trimble, "Identification of a human homologue of the vesicle-associated membrane protein (VAMP)-associated protein of $33 \mathrm{kDa}$ (VAP-33): a broadly expressed protein that binds to VAMP," Biochemical Journal, vol. 333, no. 2, pp. 247-251, 1998.

[51] T. Suzuki, K. Ishii, H. Aizaki, and T. Wakita, "Hepatitis C viral life cycle," Advanced Drug Delivery Reviews, vol. 59, no. 12, pp. 1200-1212, 2007.

[52] D. Moradpour, F. Penin, and C. M. Rice, "Replication of hepatitis C virus," Nature Reviews Microbiology, vol. 5, no. 6, pp. 453-463, 2007.

[53] J. Dubuisson and F.-L. Cosset, "Virology and cell biology of the hepatitis C virus life cycle-an update," Journal of Hepatology, vol. 61, no. 1, supplement, pp. S3-S13, 2014.

[54] T. K. H. Scheel and C. M. Rice, "Understanding the hepatitis C virus life cycle paves the way for highly effective therapies," Nature Medicine, vol. 19, no. 7, pp. 837-849, 2013.

[55] M. B. Zeisel, J. Lupberger, I. Fofana, and T. F. Baumert, "Hosttargeting agents for prevention and treatment of chronic hepatitis C-perspectives and challenges," Journal of Hepatology, vol. 58, no. 2, pp. 375-384, 2013.

[56] J. M. Baugh, J. A. Garcia-Rivera, and P. A. Gallay, "Host-targeting agents in the treatment of hepatitis $\mathrm{C}$ : a beginning and an end?" Antiviral Research, vol. 100, no. 2, pp. 555-561, 2013.

[57] J. G. O'Leary and G. L. Davis, "Hepatitis C virus replication and potential targets for direct-acting agents," Therapeutic Advances in Gastroenterology, vol. 3, no. 1, pp. 43-53, 2010.

[58] Q. Xue, H. Ding, M. Liu et al., "Inhibition of hepatitis C virus replication and expression by small interfering RNA targeting host cellular genes," Archives of Virology, vol. 152, no. 5, pp. 955962, 2007.

[59] J. Zhang, O. Yamada, T. Sakamoto et al., "Down-regulation of viral replication by adenoviral-mediated expression of siRNA against cellular cofactors for hepatitis C virus," Virology, vol. 320, no. 1, pp. 135-143, 2004. 
[60] Y. Waheed, A. Bhatti, and M. Ashraf, "RNA dependent RNA polymerase of HCV: a potential target for the development of antiviral drugs," Infection, Genetics and Evolution, vol. 14, no. 1, pp. 247-257, 2013.

[61] L. Trejo-Ávila, R. Elizondo-González, K. D. C. Trujillo-Murillo, P. Zapata-Benavides, C. Rodríguez-Padilla, and A. M. RivasEstilla, "Antiviral therapy: inhibition of hepatitis C virus expression by RNA interference directed against the NS5B region of the viral genome," Annals of Hepatology, vol. 6, no. 3, pp. 174180, 2007.

[62] U. Ali Ashfaq, M. Ansar, M. T. Sarwar, T. Javed, S. Rehman, and S. Riazuddin, "Post-transcriptional inhibition of hepatitis C virus replication through small interference RNA," Virology Journal, vol. 8, no. 1, article 112, 2011.

[63] B. Chang, C. H. Lee, J. H. Lee, and S.-W. Lee, "Comparative analysis of intracellular inhibition of hepatitis $\mathrm{C}$ virus replication by small interfering RNAs," Biotechnology Letters, vol. 32, no. 9, pp. 1231-1237, 2010.

[64] A. Upadhyay, U. Dixit, D. Manvar, N. Chaturvedi, and V. N. Pandey, "Affinity capture and identification of host cell factors associated with hepatitis C virus (+) strand subgenomic RNA," Molecular and Cellular Proteomics, vol. 12, no. 6, pp. 1539-1552, 2013.

[65] S.-C. Chan, S.-Y. Lo, J.-W. Liou et al., "Visualization of the structures of the hepatitis C virus replication complex," Biochemical and Biophysical Research Communications, vol. 404, no. 1, pp. 574-578, 2011.

[66] D. Moradpour, M. J. Evans, R. Gosert et al., "Insertion of green fluorescent protein into nonstructural protein $5 \mathrm{~A}$ allows direct visualization of functional hepatitis $\mathrm{C}$ virus replication complexes," Journal of Virology, vol. 78, no. 14, pp. 7400-7409, 2004.

[67] E. Gottlieb and J. A. Steitz, "The RNA binding protein La influences both the accuracy and the efficiency of RNA polymerase III transcription in vitro," EMBO Journal, vol. 8, no. 3, pp. 841850, 1989.

[68] S. Weser, M. Bachmann, K. H. Seifart, and W. Meibssner, "Transcription efficiency of human polymerase III genes in vitro does not depend on the RNP-forming autoantigen La," Nucleic Acids Research, vol. 28, no. 20, pp. 3935-3942, 2000.

[69] J. P. Wyles and N. D. Ridgway, "VAMP-associated proteinA regulates partitioning of oxysterol-binding protein-related protein- 9 between the endoplasmic reticulum and Golgi apparatus," Experimental Cell Research, vol. 297, no. 2, pp. 533-547, 2004.

[70] J. P. Wyles, C. R. McMaster, and N. D. Ridgway, "Vesicleassociated membrane protein-associated protein-A (VAP-A) interacts with the oxysterol-binding protein to modify export from the endoplasmic reticulum," Journal of Biological Chemistry, vol. 277, no. 33, pp. 29908-29918, 2002.

[71] Y. Jia, T. Song, C. Wei et al., "Negative regulation of MAVSmediated innate immune response by PSMA7," The Journal of Immunology, vol. 183, no. 7, pp. 4241-4248, 2009.

[72] R. Prabhu, R. F. Garry, and S. Dash, "Small interfering RNA targeted to stem-loop II of the $5 /$ untranslated region effectively inhibits expression of six HCV genotypes," Virology Journal, vol. 3, article 100, 2006.

[73] T. Watanabe, M. Sudoh, M. Miyagishi et al., "Intracellular-diced dsRNA has enhanced efficacy for silencing HCV RNA and overcomes variation in the viral genotype," Gene Therapy, vol. 13, no. 11, pp. 883-892, 2006.
[74] I. Fofana, F. Xiao, C. Thumann et al., "A novel monoclonal antiCD81 antibody produced by genetic immunization efficiently inhibits hepatitis C virus cell-cell transmission," PLOS ONE, vol. 8, no. 5, Article ID e64221, 2013. 


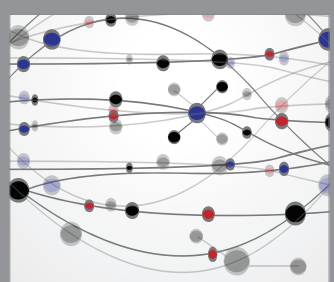

The Scientific World Journal
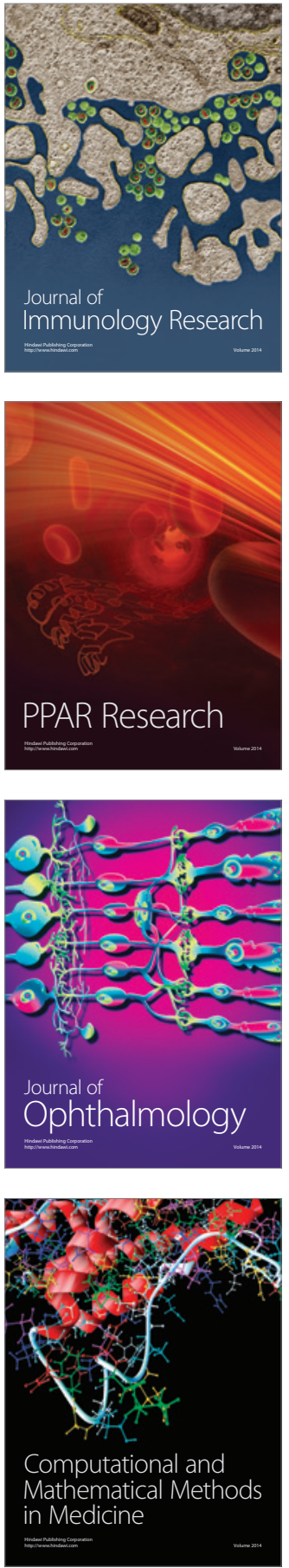

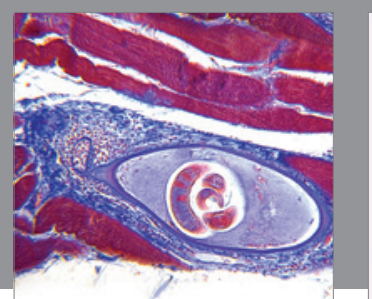

Gastroenterology Research and Practice

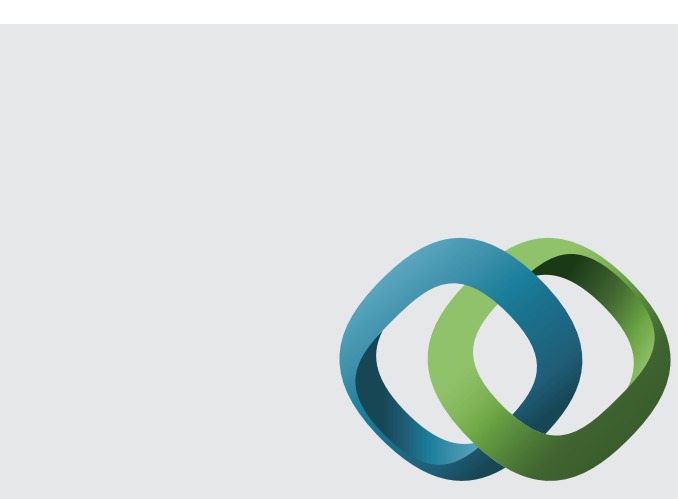

\section{Hindawi}

Submit your manuscripts at

http://www.hindawi.com
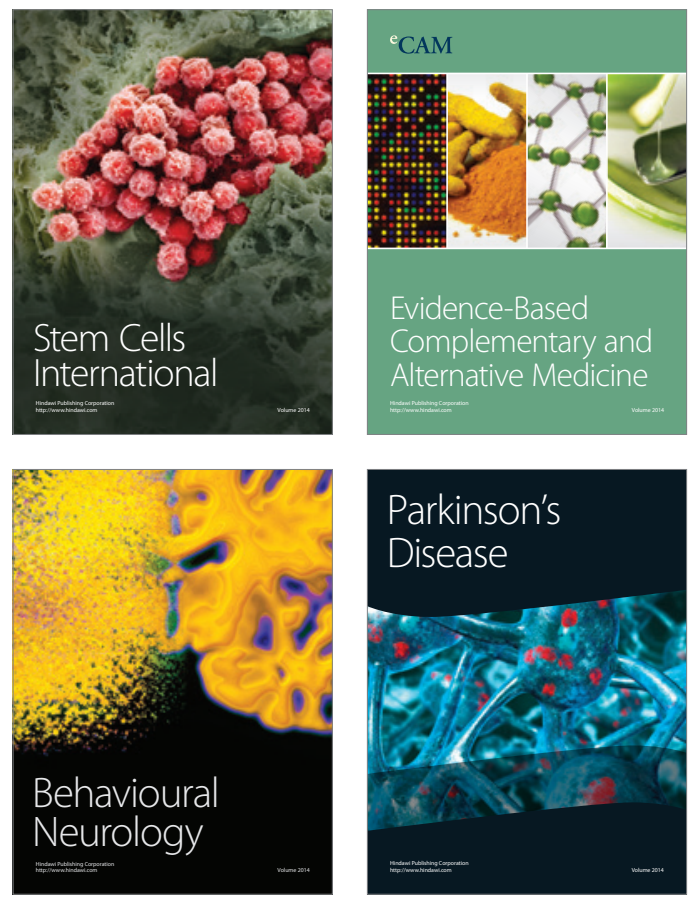
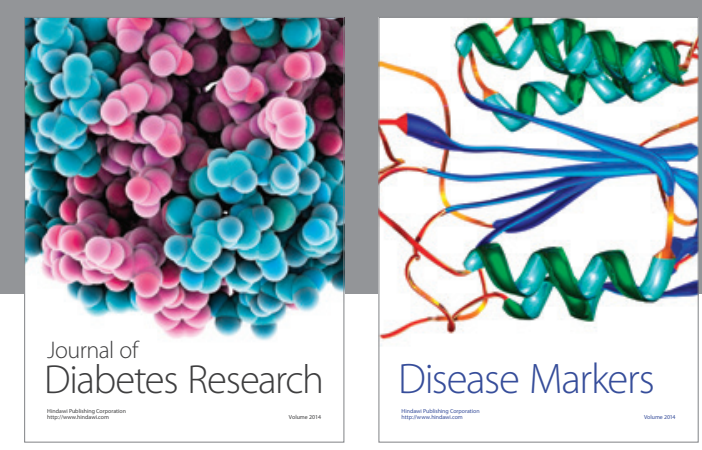

Disease Markers
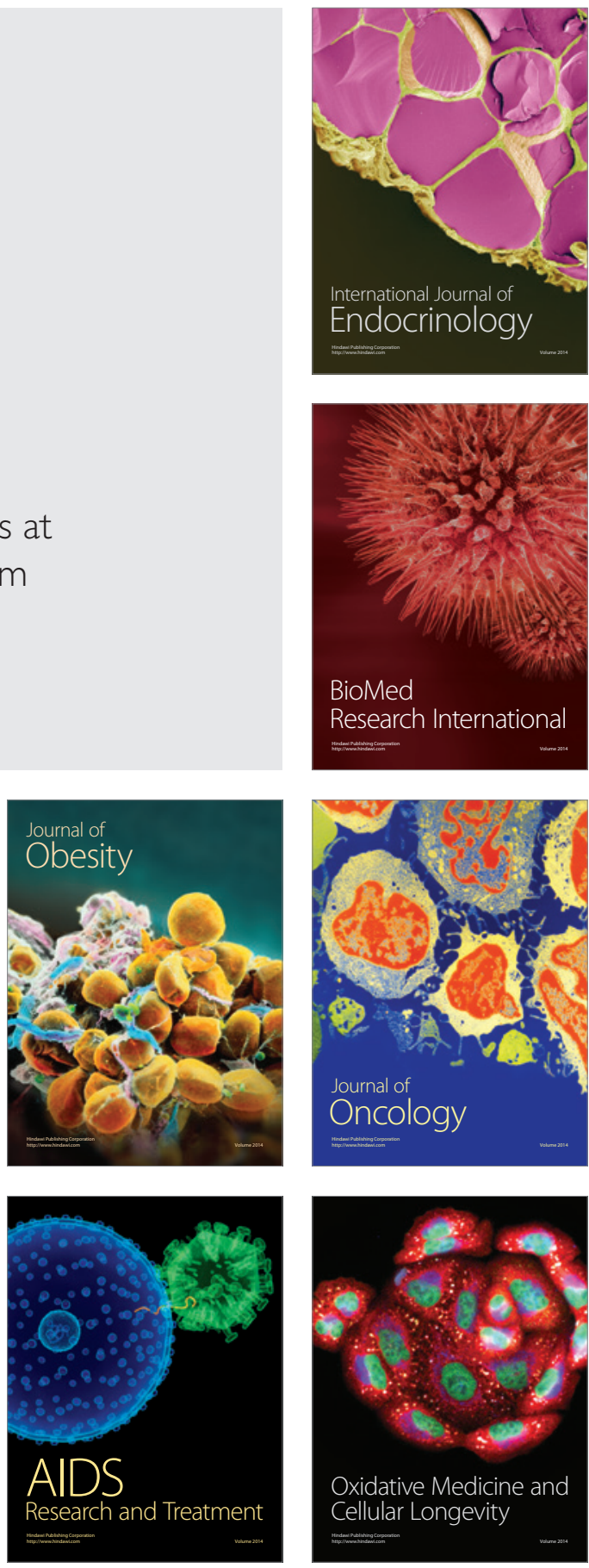